\title{
Effect of the Long-term Administration of Corticotropin-releasing Factor on the Pituitary-Adrenal and Pituitary-Gonadal Axis in the Male Rat
}

\author{
Catherine Rivier and Wylie Vale \\ Peptide Biology Laboratory, The Salk Institute, San Diego, California 92138
}

\begin{abstract}
The effect of the continuous exposure to ovine corticotropinreleasing factor (oCRF) was measured in adult male rats. The intravenous infusion of $0.75 \mathrm{nmol} \mathrm{OCRF} / \mathrm{h}$ to intact rats over a 24-h period was accompanied by a peak of ACTH and corticosterone secretion that occurred during the first 90 min of administration of the releasing factor, followed by a decrease to lower, but still above control, values. Additionally, corticotropin-releasing factor (CRF)-treated rats had decreased plasma testosterone levels. The subcutaneous administration of 0.075 or $0.75 \mathrm{nmol}$ oCRF/h to intact rats for $7 \mathrm{~d}$ also resulted in elevations of both plasma ACTH and corticosterone levels comparable to those measured after a 24-h exposure to the releasing factor, as well as dose-related hypertrophy of the adrenals and increases in pituitary ACTH content. In these animals, CRF markedly inhibited luteinizing hormone (LH) (but not follicle-stimulating hormone [FSH]), testosterone, and PRL secretion and decreased seminal vesicle weights. All the effects of CRF were mimicked by exogenously administered ACTH. By contrast, with the exception of FSH secretion, which was slightly elevated by CRF, neither CRF nor ACTH were able to significantly modify reproductive parameters in adrenalectomized animals, which suggests that the elevation of circulating levels of adrenal steroids induced by peripherally administered CRF represents major mediators of CRF-induced inhibition of fertility.

These results indicate that in the rat, the continuous stimulation of the pituitary-adrenal axis by peripherally administered CRF causes some degree of desensitization of the pituitary-adrenal axis, but is still accompanied by persistent elevations of the circulating levels of both ACTH and corticosteroids. The increased secretion of adrenal steroids by CRFtreated rats is believed to participate in the disruption of reproductive parameters observed in these rats.
\end{abstract}

\section{Introduction}

The development of response attenuation during prolonged exposure to a stimulus has been documented for a number of biological events. It is well established, for example, that the repeated administration of the hypothalamic factor, gonadotropin releasing hormone, results in the disruption of reproductive functions, a phenomenon that seems to be due in part to the response attenuation of both pituitary and gonad (review in 1).

Received for publication 18 October 1983 and in revised form 9 October 1984.

J. Clin. Invest.

(c) The American Society for Clinical Investigation, Inc.

$0021-9738 / 85 / 02 / 0689 / 06 \quad \$ 1.00$

Volume 75, February 1985, 689-694
The ACTH response to corticotropin-releasing factor $(\mathrm{CRF})^{1}$ by cultured (2) or superfused (3) pituitary cells decreases during continuous exposure to CRF. Although desensitization has been demonstrated in in vitro $(2,3)$ as well as in certain in vivo experiments (4), we have observed in the course of toxicology studies involving daily injections of CRF to rats over a 1-wk period, that this treatment resulted in hypertrophied adrenals (4). Such results suggest that ACTH release remained elevated in those animals, and are in agreement with reports indicating that repeated stimulation of the hypothalamicpituitary-adrenal axis by stress (5-10) or by serial injections of CRF (4) also does not lead to abolition of the ACTH secretory response.

In addition to its stimulatory action on the pituitaryadrenal axis $(11,12)$, we have found that CRF would markedly inhibit luteinizing hormone $(\mathrm{LH})$ release when injected into the lateral ventricle of male or female rats, and that this effect was not mediated through steroids of adrenal or gonadal origin, or through increased activity of the corticotroph (13). We have, therefore, examined the effect of the continuous peripheral administration of CRF over a $24-\mathrm{h}$ or $7-\mathrm{d}$ period on both the pituitary-adrenal and pituitary-gonadal axis in both intact and adrenalectomized rats, and compared it with the effect of longterm infused ACTH.

\section{Methods}

Animals. Adult Sprague-Dawley male rats $(230-250 \mathrm{~g})$ were used throughout this study. They were fed Purina Chow (Ralston Purina Co., St. Louis, MO) and water ad lib., and housed under a 12-h light/ 12-h darkness regimen (lights on at $0700 \mathrm{~h}$ ). When appropriate, adrenalectomy was performed under ether anesthesia via the lumbar approach, 6-7 $\mathrm{d}$ before the start of the experiment.

For the experiment dealing with exposure of CRF for $24 \mathrm{~h}$, the animals were equipped with indwelling jugular and femoral catheters (12). The cannulas placed in the femoral artery were used for serial blood sampling and the cannulas placed in the jugular vein were connected to Sage infusion pumps (A. H. Thomas Co., Philadelphia, PA) that delivered $0.2 \mathrm{ml} / \mathrm{h}$. The cannulas were protected by a metal coil and placed on a swivel. Surgery was performed $24 \mathrm{~h}$ before the start of the experiment. On the day of the assay, a first blood sample was taken, followed by starting of the infusion. Subsequent blood samples were obtained at the times described under Results, and immediately replaced by an equivalent volume of erythrocytes (resuspended in normal saline) from donor rats. CRF was dissolved in 0.04 $M$ phosphate-buffered saline with $0.1 \%$ bovine serum albumin (BSA) and $0.01 \%$ ascorbic acid, and placed in $10-\mathrm{ml}$ disposable glass syringes.

For the experiment dealing with exposure to the peptides over a 7-d period, oCRF or ACTH (Cortrosyn), dissolved in $0.04 \mathrm{M}$ phosphatebuffered saline containing $0.1 \% \mathrm{BSA}$ and $0.01 \%$ ascorbic acid, were

1. Abbreviations used in this paper: $\mathrm{CRF}$, corticotropin-releasing factor; FSH, follicle-stimulating hormone; HR, heart rate; LH, luteinizing hormone; MAP, mean arterial pressure; oCRF, ovine corticotropinreleasing factor; PRL, prolactin. 
placed in Alzet osmotic minipumps (model 2001, Alza Inc., Palo Alto, CA). The minipumps have a capacity of $225 \mu$ land a nominal pumping rate of delivery rate was $1 \mu \mathrm{l} / \mathrm{h}$. They were loaded to their maximum capacity, so that they would be completely exhausted in $8 \mathrm{~d}$. The Alzet pumps were inserted dorsally under the skin during light ether anesthesia. In previous experiments, we have also connected the pumps to the jugular vein, and obtained comparable results. The stability of CRF in the Alzet pumps was checked at the end of the experiment by radioimmunoassay (14) and bioassay (3) of the remaining content of the pumps. Neither assay indicated any significant loss in either immuno- or bioactivity.

At the end of the 7-d experiment, the animals were decapitated, and the adrenals, testes, seminal vesicles (emptied), and ventral prostates were freed of fat and weighed to the nearest $0.1 \mathrm{mg}$. The pituitaries were placed in $1 \mathrm{ml} 0.1 \mathrm{~N} \mathrm{HCl} / 1 \mathrm{~N} \mathrm{HoAc}$, boiled for $5 \mathrm{~min}$, homogenized, and frozen.

Hormone assays. Plasma ACTH (12), corticosterone (12), prolactin (PRL) (3), testosterone (1), and CRF (14) levels were measured as previously described. Plasma LH values were measured by the ovineovine procedure of Niswender et al. (15). Pituitary ACTH content was measured after dilution of the samples with the radioimmunoassay buffer.

Hormones. OCRF was synthesized by solid phase methodology (16) and provided by Dr. Jean Rivier, Salk Institute. Cortrosyn [ACTH-(124)] was purchased from Organon, Inc., West Orange, NJ.

Cardiovascular parameters. Heart rate and mean arterial pressure were measured according to Fisher et al. (17).

Statistical analysis. Differences between treatments were analyzed by analysis of variance.

\section{Results}

Effect of intravenous administration of oCRF to intact rats for $24 \mathrm{~h}$. Plasma ACTH levels of intact rats receiving $0.75 \mathrm{nmol}$ oCRF/h for $24 \mathrm{~h}$ reached peak values (range, $0.690-0.985 \mathrm{ng}$ / $\mathrm{ml}$ ) by 45-90 min after the beginning of the infusion, then declined to lower values (range, $0.240-0.355 \mathrm{ng} / \mathrm{ml}$ ) for the remainder of the experiment (Fig. 1). Corticosterone secretion showed a peak increase at 45-90 min (range, 0.141-0.335 $\mathrm{g}$ / $\mathrm{ml}$ ), then decreased to levels ranging from 0.115 to $0.148 \mu \mathrm{g} /$ $\mathrm{ml}$ from 10 to $24 \mathrm{~h}$ after the treatment. Control animals showed typical circadian rhythms (Fig. 1) with plasma ACTH and corticosterone levels that were significantly lower than those of CRF-treated rats at all times (ACTH, $\leq 50-75 \mathrm{pg} / \mathrm{ml}$; corticosterone, $\leq 0.012-0.063 \mu \mathrm{g} / \mathrm{ml}$ ). Plasma testosterone levels, measured at the end of the experiment only, were $2.54 \pm 0.32$ $\mathrm{ng} / \mathrm{ml}$ for control rats and $1.21 \pm 0.27 \mathrm{ng} / \mathrm{ml}$ for CRF-treated rats $(P \leq 0.05)$. Plasma $P R L$ levels were $5.95 \pm 0.52 \mathrm{ng} / \mathrm{ml}$ for control rats and $5.63 \pm 0.47 \mathrm{ng} / \mathrm{ml}$ for CRF-treated rats $(P>0.05)$.

Effect of subcutaneous administration of oCRF or $A C T H$ to intact rats for $7 \mathrm{~d}$. The administration of $0.075 \mathrm{nmol}$ $\mathrm{oCRF} / \mathrm{h}$ to intact rats was not accompanied by significantly elevated levels of circulating CRF (control, $\leq 0.150 \mathrm{ng} / \mathrm{ml}$; $0.075 \mathrm{nmol}$ oCRF $/ \mathrm{h}, 0.177 \pm 0.027 \mathrm{ng} / \mathrm{ml} ; P>0.05$ ). This treatment caused a marked increase in pituitary ACTH content, and a moderate elevation in plasma ACTH and corticosterone values, but no significant changes in adrenal weights (Table I). Additionally, it induced a slight decrease in seminal vesicles' weights, but no alteration of testes or ventral prostate weights despite a significant lowering of testosterone secretion (Table II). Exposure to $0.75 \mathrm{nmol} \mathrm{oCRF/h}$, which corresponded to markedly elevated values of circulating CRF (3.114 $\pm 0.663 \mathrm{ng} /$ $\mathrm{ml}$ ), was accompanied by a significant increase in pituitary
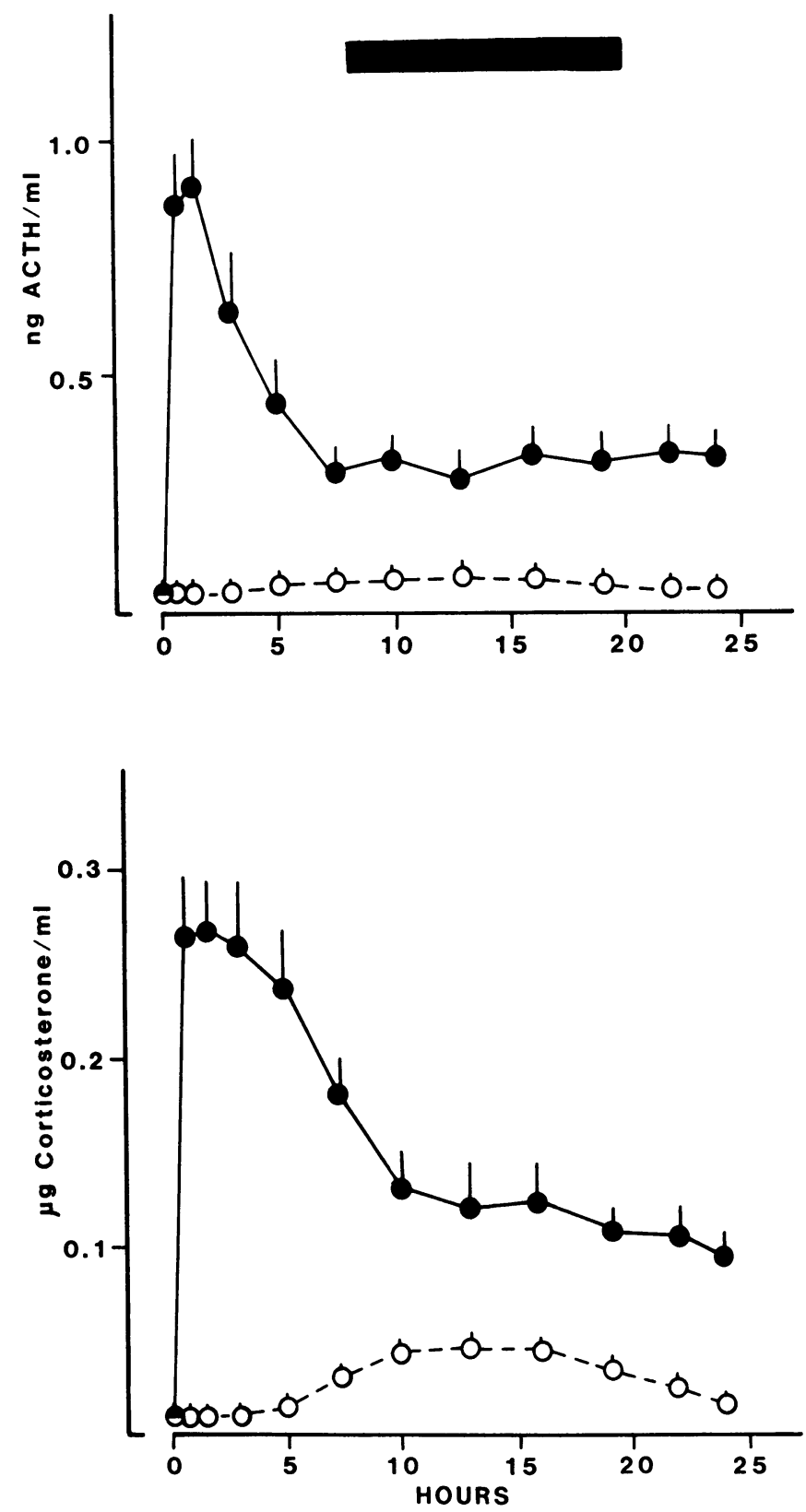

Figure 1. Effect of the intravenous infusion of the vehicle or 0.75 $\mathrm{nmol} \mathrm{OCRF} / \mathrm{h}$ on ACTH and corticosterone secretions by intact rats over a 24-h period. O, control rats; $\bullet$, CRF-treated rats. Each point represents the mean \pm SEM of six-nine animals. $\square$ indicates the period of darkness.

ACTH content, adrenal weights, and plasma ACTH and corticosterone levels (Table I) as well as decreases in plasma testosterone values and the weights of androgen-dependent organs (Table II). Plasma LH levels were significantly lowered by the higher dose of CRF, but there were no significant changes in FSH secretion.

In these intact rats, the continuous exposure to 10,30 , or $100 \mathrm{mU} \mathrm{ACTH} / \mathrm{h}$ was accompanied by dose-related increases in circulating levels of ACTH and corticosterone (Table I), as well as decreases in plasma $\mathrm{LH}$, testosterone values, and seminal vesicle weights (Table II). Both CRF and ACTH caused a significant decrease in PRL secretion (Table III). 
Table I. Effect of the Administration of oCRF or ACTH for $7 d$ on the Hypothalamic-Pituitary-Adrenal Axis of Intact Rats

\begin{tabular}{lcclcc}
\hline Treatment & $N$ & ACTH & ACTH pituitary content & Corticosterone & Adrenals \\
& & $p g / m l$ & $\mu g / p i t$ & $n g / m l$ & \\
& & & & & \\
Control & 10 & $51.3 \pm 2.6^{*}$ & $1.54 \pm 0.12$ & $17.8 \pm 3.2$ & $41.2 \pm 3.3$ \\
$0.075 \mathrm{nmol}$ oCRF/h & 10 & $194.9 \pm 19.1 \ddagger$ & $2.20 \pm 0.15 \ddagger$ & $28.2 \pm 7.4 \S$ & $41.4 \pm 4.0^{\prime \prime}$ \\
$0.75 \mathrm{nmol}$ oCRF/h & 10 & $347.8 \pm 56.2 \ddagger$ & $2.68 \pm 0.24 \ddagger$ & $122.3 \pm 15.8 \ddagger$ & $58.3 \pm 5.3 \ddagger$ \\
$10 \mathrm{mU} \mathrm{ACTH/h}$ & 10 & $198.3 \pm 10.5 \ddagger$ & ND & $21.0 \pm 2.5^{\prime \prime}$ & $38.9 \pm 2.4^{\prime \prime}$ \\
$30 \mathrm{mU} \mathrm{ACTH/h}$ & 6 & $396.7 \pm 14.4 \ddagger$ & ND & $105.3 \pm 14.64 \ddagger$ & $51.4 \pm 4.8^{\prime \prime}$ \\
$100 \mathrm{mU} \mathrm{ACTH/h}$ & 6 & $834.3 \pm 50.6 \ddagger$ & ND & $293.7 \pm 31.4 \ddagger$ & $133.3 \pm 10.2 \ddagger$ \\
\hline
\end{tabular}

* Data are presented \pm SEM. ND, not determined; $¥ P \leq 0.01 ; \S P \leq 0.05 ; \quad " P>0.05$.

Mean arterial pressure (MAP) and heart rate (HR) were measured in order to document possible cardiovascular changes during the mid-course of the experiments. Four control rats and four rats receiving $0.75 \mathrm{nmol} \mathrm{CRF} / \mathrm{h}$ were monitored before the start of the experiment (day 0 ), as well as on days 3 and 7 of the infusion. Mean HR for control animals on days 0,3 , and 7 was $349.2 \pm 8.5,355.0 \pm 8.4$, and $350.9 \pm 7.6$ beats/ $\mathrm{min}$; their MAP was $110.3 \pm 4.9,107.5 \pm 3.2$, and $109.1 \pm 4.2$ $\mathrm{mmHg}$, respectively. Mean $\mathrm{HR}$ of CRF-treated rats was $335 \pm 10.2$, $329 \pm 11.3$, and $330 \pm 10.5$ beats $/ \mathrm{min}$, and their MAP was $109.5 \pm 3.7,107.5 \pm 3.2$, and $105.4 \pm 6.3 \mathrm{mmHg}$. These differences were not statistically significant. These animals were not included in the results of Tables I and II.

Effect of administration of $o C R F$ or ACTH to adrenalectomized rats for $7 d$. The administration of $0.75 \mathrm{nmol}$ oCRF/ $\mathrm{h}$ to adrenalectomized rats produced a slight, though not statistically significant elevation in plasma ACTH levels, but no alteration in pituitary ACTH content. There was a slight $(P>0.05)$ decrease in plasma $\mathrm{LH}$ and testosterone values, as well as the weights of androgen-dependent organs, and a small but significant $(P \leq 0.01)$ increase in plasma follicle-stimulating hormone (FSH) levels. The infusion of $100 \mathrm{mU} \mathrm{ACTH/h}$, which markedly increased circulating levels of ACTH, did not modify testosterone release or the weights of sex organs (Table IV). Both CRF and ACTH decreased plasma PRL levels (Table III).

\section{Discussion}

In the rat, repeated as well as continuous stresses are usually accompanied not only by unimpaired multiple increases in
ACTH secretion, but also by a state of hyper-responsiveness of the adrenocortical system (5-10). This suggests that elevated levels of plasma corticosteroid do not necessarily prevent the corticotrophs' responsiveness to hypothalamic activation.

Human pathological conditions also arise, which are characterized by increased corticosteroid as well as ACTH release, and the question as to whether CRF secretion is elevated in such cases is not yet resolved. Our results indicate that in the rat, the long-term exposure to exogenous CRF results in persistently high levels of circulating ACTH as well as corticosterone. This suggests that in the presence of elevated levels of CRF, a new set point for ACTH and corticosterone is reached, and raises the possibility that certain states of adrenal hyper-responsiveness, such as Cushing's disease and alcoholic pseudo-Cushing's, might be associated at some stage with higher output of CRF. Note, however, that though the infusion of CRF for $24 \mathrm{~h}$ or $7 \mathrm{~d}$ resulted in markedly elevated levels of plasma ACTH and corticosterone by the end of the experiment, these values were significantly lower than those present during the early part of the infusion. This observation indicates that though the secretory rate of the pituitary and the adrenals can remain elevated during continuous exposure of the rat to CRF, it nevertheless exhibits, as would have been expected from in vitro studies $(2,3)$, some desensitization. Note that since Schulte et al. (18) have reported that the continuous administration of low doses of CRF did not consistently elevate ACTH and cortisol release in man and in nonhuman primates, it is possible that the ability of the pituitary-adrenal axis to maintain its responsiveness to $\mathrm{CRF}$ is species-specific.

Comparison of the effects of CRF and ACTH indicates that doses of CRF and exogenously administered ACTH that result in comparable levels of circulating ACTH have different

Table II. Effect of the Administration of oCRF or ACTH for $7 d$ on Reproductive Parameters of Intact Rats

\begin{tabular}{|c|c|c|c|c|c|c|c|}
\hline Treatment & $N$ & LH & FSH & Testosterone & Testes & SV & VP \\
\hline & & $n g / m l$ & $n g / m l$ & $n g / m l$ & $g m$ & $m g$ & $m g$ \\
\hline Control & 10 & $1.07 \pm 0.09$ & $73.7 \pm 5.3^{*}$ & $2.74 \pm 0.38$ & $3.12 \pm 0.06$ & $243.7 \pm 17.6$ & $203.2 \pm 14.7$ \\
\hline $0.075 \mathrm{nmol}$ oCRF $/ \mathrm{h}$ & 10 & $0.92 \pm 0.08^{*}$ & $73.1 \pm 4.6^{*}$ & $1.69 \pm 0.32 \ddagger$ & $2.99 \pm 0.07^{*}$ & $194.9 \pm 17.3 \ddagger$ & $173.1 \pm 11.9^{*}$ \\
\hline $0.75 \mathrm{nmol} \mathrm{oCRF} / \mathrm{h}$ & 10 & $0.38 \pm 0.03 \S$ & $74.5 \pm 5.1^{*}$ & $0.57 \pm 0.33 \S$ & $2.98 \pm 0.07^{*}$ & $105.3 \pm 8.8 \S$ & $136.0 \pm 14.2 \S$ \\
\hline $10 \mathrm{mU} \mathrm{ACTH} / \mathrm{h}$ & 10 & $0.79 \pm 0.05 \ddagger$ & ND & $1.45 \pm 0.25 \ddagger$ & $3.04 \pm 0.12^{*}$ & $203.8 \pm 16.2 \ddagger$ & $183.1 \pm 14.66^{*}$ \\
\hline $30 \mathrm{mU} \mathrm{ACTH} / \mathrm{h}$ & 6 & $0.67 \pm 0.04 \S$ & ND & $1.28 \pm 0.27 \S$ & $3.05 \pm 0.14^{*}$ & $205.7 \pm 10.3 \ddagger$ & $185.7 \pm 12.3^{*}$ \\
\hline $100 \mathrm{mU} \mathrm{ACTH} / \mathrm{h}$ & 6 & $0.49 \pm 0.03 \S$ & ND & $0.90 \pm 0.34 \S$ & $3.08 \pm 0.13^{*}$ & $161.0 \pm 10.5 \S$ & $191.4 \pm 13.5^{*}$ \\
\hline
\end{tabular}

SV, seminal vesicles; VP, ventral prostate; ${ }^{*} P>0.05 ; \ddagger P \leq 0.05 ; \S P \leq 0.01 ; \mathrm{ND}$, not determined. 
Table III. Effect of oCRF or ACTH on PRL Secretion

\begin{tabular}{lll}
\hline Treatment & $N$ & PRL \\
\hline & & $n g / \mathrm{ml}$ \\
Intact rats, control & 8 & $7.16 \pm 1.37$ \\
Intact rats, $0.075 \mathrm{nmol}$ oCRF/h & 7 & $6.41 \pm 1.17 *$ \\
Intact rats, $0.75 \mathrm{nmol}$ oCRF/h & 7 & $3.67 \pm 0.63 \ddagger$ \\
Intact rats, $30 \mathrm{mU} \mathrm{ACTH/h}$ & 6 & $4.10 \pm 0.53 \ddagger$ \\
Intact rats, $100 \mathrm{mU} \mathrm{ACTH} / \mathrm{h}$ & 6 & $3.81 \pm 0.60 \ddagger$ \\
ADX rats, control & 9 & $8.69 \pm 0.68$ \\
ADX rats, $0.75 \mathrm{nmol}$ oCRF/h & 9 & $5.50 \pm 0.57 \ddagger$ \\
ADX rats, $100 \mathrm{mU} \mathrm{ACTH/h}$ & 9 & $5.94 \pm 0.63 \ddagger$ \\
\hline
\end{tabular}

ADX, adrenalectomized.

$* P>0.05$.

$\ddagger P \geq 0.01$.

effects on testosterone secretion. At present, we cannot rule out that high doses of CRF might exert some direct inhibitory action on the testes, which might at least partially account for the more marked lowering of androgen release observed in CRF-treated rats.

As has been extensively documented in a number of species including man (11, 18-22), the acute intravenous administration of CRF causes peripheral vasodilation and hypotension, and an accompanying stress-induced activation of the hypothalamicpituitary-adrenal axis. It seems improbable, however, that the CRF-induced inhibition of reproductive functions was solely due to a nonspecific stress effect, since it was not observed in adrenalectomized rats, in which CRF causes changes in cardiovascular parameters that are comparable to those measured in intact animals (23).

Prolonged exposure to stress has been reported to exert deleterious effects on reproductive functions (23-31), but there is still controversy concerning the mechanisms involved. Some investigators have suggested that stress-induced increased levels of circulating corticosteroids and/or adrenal androgens would decrease pituitary responsiveness to $\mathrm{GnRH}$, and therefore $\mathrm{LH}$ secretion (32-36), or exert a direct inhibitory action on steroidogenesis $(31,33,37,38)$. Others have reported that $\mathrm{ACTH}$, but not corticosterone, could delay puberty (39), interrupt pregnancy (40-42), and inhibit ovulation (43). We have recently observed that the intracerebroventricular administration of CRF markedly lowered LH secretion in gonadectomized/ adrenalectomized rats, while acutely large doses of peripherally administered CRF were without effect (13). We had additionally suggested that this inhibition was not mediated through an increase in ACTH secretion, since blockade of the action of CRF on the corticotrophs by dexamethasone did not interfere with CRF-induced lowering of $\mathrm{LH}$ release (13). The results presented here indicate that high amounts of CRF administered subcutaneously would significantly inhibit testosterone secretion and decrease ventral prostate weights. The observation that this effect can be at least partially mimicked by ACTH in intact, but not adrenalectomized rats, coupled with the inability of peripherally administered CRF to modify reproductive parameters in the absence of circulating steroids of adrenal origin, suggests that adrenal steroids represent major direct modulators of the deleterious action on reproductive parameters of peripherally injected CRF. Indeed, our observation that CRF could lower plasma LH levels in intact, but not adrenalectomized rats, supports the hypothesis previously proposed by Mann et al. (35) that long-term ACTH infusions would inhibit LH secretion through adrenal androgen-mediated changes in pituitary activity. Our data, however, do not permit us to rule out that adrenal glucocorticoids may have also exerted a direct inhibitory effect on the testes (37).

Finally, our results indicate that the peripheral administration of CRF and ACTH caused some inhibition of PRL secretion in both intact and adrenalectomized rats. These findings are in contrast with reports that increases in circulating levels of ACTH have been shown to stimulate PRL release in female rats (44), but agree with the observation by Collu et al. (45) that chronic stress causes a marked decrease in plasma PRL levels. Since CRF has little or no direct effect on the mammotroph (3), but increases adrenal steroids shown to inhibit PRL secretion (46), it might either have acted through a modification of the steroid milieu or have penetrated areas of the brain involved in the control of PRL release.

We conclude that in the intact rat, the continuous stimulation of the pituitary-adrenal axis by CRF, though causing some degree of desensitization, is nevertheless accompanied by persistent elevations of the circulating levels of both ACTH and corticosteroids, as well as by disruption of reproductive parameters. Whether these observations in the rat can be related to various pathological conditions seen in man needs to be further investigated.

\section{Acknowledgments}

The authors wish to thank N. Keating, P. Resch, M. Newberry, P. Hernandez, J.-L. Boone, M. Tam, A. Corrigan, C. Douglas, R. Kaiser,

Table IV. Effect of the Administration of oCRF or ACTH for $7 d$ to Adrenalectomized Rats

\begin{tabular}{|c|c|c|c|c|c|c|c|c|c|}
\hline & $N$ & ACTH & $\begin{array}{l}\text { ACTH } \\
\text { pituitary } \\
\text { content }\end{array}$ & LH & FSH & Testosterone & Testes & SV & VP \\
\hline & & $n g / m l$ & $\mu g / p i t$ & $n g / m l$ & $n g / m l$ & $n g / m l$ & $g$ & $m g$ & $m g$ \\
\hline Control & 10 & $2.19 \pm 0.30$ & $4.98 \pm 0.18$ & $1.12 \pm 0.10$ & $89.4 \pm 9.9$ & $2.87 \pm 0.39$ & $3.33 \pm 0.11$ & $277.2 \pm 17.4$ & $240.7 \pm 20.3$ \\
\hline $0.75 \mathrm{nmol}$ oCRF $/ \mathrm{h}$ & 10 & $2.83 \pm 0.32^{*}$ & $5.17 \pm 0.46^{*}$ & $1.05 \pm 0.08^{*}$ & $133.3 \pm 11.2 \ddagger$ & $2.18 \pm 0.20^{*}$ & $3.19 \pm 0.07^{*}$ & $251.5 \pm 20.5^{*}$ & $224.1 \pm 26.5^{*}$ \\
\hline $100 \mathrm{mU} \mathrm{ACTH} / \mathrm{h}$ & 10 & $4.38 \pm 0.41 \ddagger$ & ND & $0.98 \pm 0.09^{*}$ & ND & $2.93 \pm 0.29^{*}$ & $3.28 \pm 0.05^{*}$ & $272.5 \pm 19.8^{*}$ & $241.1 \pm 20.7^{*}$ \\
\hline
\end{tabular}

SV, seminal vesicles; VP, ventral prostate; $* P>0.05 ; \ddagger P \leq 0.01$; ND, not determined. 
R. Galyean, and R. McClintock for expert technical assistance; Dr. Jean Rivier for providing CRF; Dr. D. Orth for the gift of ACTH antiserum, and Dr. L. Fisher for measuring heart rate and mean arterial pressure. We acknowledge the help of D. Weigand, G. Swart, S. Logan, and B. Hensley for manuscript preparation. We are also grateful to the National Pituitary Agency for generously providing the PRL and LH RIA kits.

This study was supported by National Institutes of Health grants AA-03504, AM-26741, HD-13527; NO1-HD-2-2807; The Rockefeller Foundation; The Texas-Salk Institute Foundation; and The March of Dimes Birth Defects Foundation. Research was conducted in part by The Clayton Foundation for Research, California Division. Dr. C. Rivier and Dr. W. Vale are Clayton Foundation Investigators.

\section{Referénces}

1. Rivier, C., W. Vale, and J. Rivier. 1983. Effects of gonadotropin releasing hormone/agonists and antagonists on reproductive functions. J. Med. Chem. 26:1545-1550.

2. Hoffman, A., and T. Reisine. 1983. CRF desensitization in cultured anterior pituitary cells. Proc. 65th Ann. Meeting Endocr. Soc., San Antonio, TX. 264. (Abstr.)

3. Vale, W., J. Vaughan, M. Smith, G. Yamamoto, J. Rivier, and C. Rivier. 1983. Effects of synthetic ovine CRF, glucocorticoids, catecholamines, neurophypophysial peptides and other substances on cultured corticotropic cells. Endocrinology. 113:1121-1131.

4. Rivier, C., and W. Vale. 1983. Influence of the frequency of ovine corticotropin-releasing factor (CRF) administration on ACTH and corticosterone secretion in the rat. Endocrinology. 113:1422-1426.

5. Dallman, M. F., and M. T. Jones. 1973. Corticosteroid feedback control of ACTH secretion: Effect of stress-induced corticosterone secretion on subsequent stress responses in the rat. Endocrinology. 92:1367-1375.

6. Cook, D. M., J. W. Kendall, M. A. Greer, and R. M. Kramer. 1973. The effect of acute or chronic ether stress on plasma ACTH concentration in the rat. Endocrinology. 93:1019-1024.

7. Sakellaris, P. C., and J. Vernikos-Danellis. 1975. Increased rate of response of the pituitary-adrenal system in rats adapted to chronic stress. Endocrinology. 97:597-602.

8. De Souza, E. B., and G. R. Van Loon. 1982. Stress-induced inhibition of the plasma corticosterone response to a subsequent stress in rats: a non-adrenocorticotropin-mediated mechanism. Endocrinology. 110:23-33.

9. Gann, D. S., G. L. Cryer, and J. C. Pilkle, Jr. 1977. Physiological inhibition and facilitation of adrenocortical response to hemorrhage. Am. J. Physiol. 232:125-129.

10. Daniels-Severs, A., A. Goodwin, L. C. Heil, J. VernikosDanellis, and M. F. Dallman. 1973. Effect of chronic crowding and cold on the pituitary-adrenal system: responsiveness to an acute stimulus during chronic stress. Pharmacology. 9:348-357.

11. Vale, W., J. Spiess, C. Rivier, and J. Rivier. 1981. Characterization of a 41 residue ovine hypothalamic peptide that stimulates the secretion of corticotropin and $\beta$-endorphin. Science (Wash. DC). 213:1394-1397.

12. Rivier, C., M. Brownstein, J. Spiess, J. Rivier, and W. Vale. 1982. In vivo CRF-induced secretion of $\mathrm{ACTH}, \beta$-endorphin and corticosterone. Endocrinology. 110:272-278.

13. Rivier, C., and W. Vale. 1984. Influence of corticotropinreleasing factor (CRF) on reproductive functions in the rat. Endocrinology. 114:914-921.

14. Vale, W., J. Vaughan, G. Yamamoto, T. Bruhn, C. Douglas, D. Dalton, C. Rivier, and J. Rivier. 1983. Assay of corticotropin releasing factor. Neuroendocrine Peptides. Methods Enzymol. 565577.

15. Niswender, G. D., A. R. Midgley, S. E. Monroe, and L. E. Reichert. 1968. Radioimmunoassay for rat luteinizing hormone with anti-ovine LH serum and ovine $\mathrm{LH}^{131} \mathrm{I}$. Proc. Soc. Exp. Biol. Med. 128:807-811.
16. Rivier, J., J. Spiess, C. Rivier, R. Galyean, W. Vale, and K. Lederis. 1983. Solid phase synthesis of amunine (CRF), sauvagine and two urotensin I. 17th European Peptide Symposium, Aug. 29-Sept. 3, 1982. Karel Blaha and Peter Malon (eds.) Walter de Gruyter \& Co., Berlin. 597-602.

17. Fisher, L. A., J. Rivier, C. Rivier, J. Spiess, W. Vale, and M. R. Brown. 1982. Corticotropin-releasing factor (CRF): central effects on mean arterial pressure and heart rate in rats. Endocrinology. 110:2222-2224.

18. Schulte, H. M., G. P. Chrousos, E. H. Oldfield, J. D. Booth, P. W. Gold, G. C. Cutler, and D. L. Loriaux. 1983. Continuous corticotropin releasing factor administration in man and nonhuman primates. XIV Acta Endocrinicol. Congr. Stockholm. 116. (Abstr.)

19. Chrousos, G. P., H. M. Schulte, D. L. Loriaux, E. H. Oldfield, and P. W. Gold. 1983. Corticotropin releasing factor: basic and clinical studies. Psychopharmacol. Bull. 19:416.

20. Chrousos, G. P., H. M. Schulte, E. H. Oldfield, G. B. Cutler, P. N. Gold, and D. L. Loriaux. 1983. The effects of corticotropin releasing factor in man. Clin. Res. 31:269A. (Abstr.)

21. Brown, M. R., L. A. Fisher, J. Spiess, J. Rivier, C. Rivier, and W. Vale. 1982. Comparison of the biologic actions of corticotropin. releasing factor and sauvagine. Regul. Pept. 4:107-114.

22. Orth, D. N., R. V. Jackson, G. S. DeCherney, C. R. DeBold, A. N. Alexander, D. P. Island, J. Rivier, C. Rivier, J. Spiess, and W. Vale. 1983. Effect of synthetic ovine corticotropin-releasing factor: dose response of plasma adrenocorticotropin and cortisol. J. Clin. Invest. 71:587-595.

23. Fisher, L. A., G. Jessen, and M. R. Brown. 1983. Mechanism to elevate mean arterial pressure and heart rate. Regul. Pept. 5:153161.

24. Euker, J. S., J. Meites, and G. D. Riegle. 1973. Effects of acute stress on serum LH and prolactin in intact, castrated and dexamethasone-treated male rats. Endocrinology. 96:85-92.

25. Krulich, L., E. Hefco, P. Illner, and C. B. Read. 1974. The effects of acute stress on the secretion of LH, FSH, prolactin and GH in the normal male rat, with comments on their statistical evaluation. Neuroendocrinology. 16:293-311.

26. Nequin, L. G., J. A. Alvarez, and C. S. Campbell. 1975. Alterations in steroid and gonadotropin release resulting from surgical stress during the morning of proestrus in 5-day cyclic rats. Endocrinology. 97:718-725.

27. Blake, C. A. 1975. Effects of "Stress" on pulsatile luteinizing hormone release in ovariectomized rats. Proc. Soc. Exp. Biol. Med. 148:813-816.

28. Collu, R., Y. Tache, and J. R. Bucharme. 1979. Hormonal modifications induced by chronic stress in rats. J. Steroid Biochem. 22:989-1000.

29. Rhees, R. W., and D. E. Fleming. 1981. Effects of malnutrition, maternal stress, or ACTH injections during pregnancy on sexual behavior of male offspring. Physiol. Behav. 27:879-882.

30. Plas-Roser, S., and C. Aron. 1981. Stress related effects in the control of sexual receptivity and in the secretion of progesterone by the adrenals in cyclic female rats. Physiol. Behav. 27:261-264.

31. Charpenet, G., Y. Tache, M. G. Forest, F. Haour, J. M. Saez, M. Bernier, J. R. Ducharme, and R. Collu. 1981. Effects of chronic intermittent immobilization stress on rat testicular androgenic function. Endocrinology. 109:1254-1258.

32. Baldwin, D. M., and C. H. Sawyer. 1974. Effects of dexamethasone on LH release and ovulation in the cyclic rat. Endocrinology. 94:1397-1403.

33. Saez, J. M., A. M. Morera, F. Haour, and D. Evain. 1977. Effects of in vivo administration of dexamethasone, corticotropin and human chorionic gonadotropin on steroidogenesis and protein and DNA synthesis of testicular interstitial cells in prepubertal rats. Endocrinology. 101:1256.

34. Baldwin, D. M. 1979. The effect of glucocorticoids on estrogendependent luteinizing hormone release in the ovariectomized rat and 
on gonadotropin secretion in the intact female rat. Endocrinology. 105: 120-128.

35. Mann, D. R., G. G. Jackson, and M. S. Blank. 1982. Influence of adrenocorticotropin and adrenalectomy on gonadotropin secretion in immature rats. Neuroendocrinology. 34:20-26.

36. Charpenet, G., Y. Tache, M. Bernier, J. R. Ducharme, and R. Collu. 1982. Stress-induced testicular hyposensitivity to gonadotropin in rats. Role of the pituitary gland. Biol. Reprod. 27:616-623.

37. Bambino, T. H., and A. J. W. Hsueh. 1981. Direct inhibitory effect of glucocorticoids upon testicular luteinizing hormone receptor and steroidogenesis in vivo and in vitro. Endocrinology. 108:21422148.

38. Hagino, N., M. Watanabe, and J. W. Goldzieher. 1969. Inhibition by adrenocorticotrophin of gonadotrophin-induced ovulation in immature female rats. Endocrinology. 84:308-314.

39. Ramaley, J. A., and N. B. Schwartz. 1980. The pubertal process in the rat. Neuroendocrinology. 30:213-219.

40. Yang, W. H., W. P. Yang, and L. L. Lin. 1969. Interruption of pregnancy in the rat by administration of ACTH. Endocrinology. 85:1282-1285.

41. Velardo, J. J. 1957. Action of adrenocorticotropin on pregnancy and litter size in rats. Am. J. Physiol. 191:319-323.

42. Kittinger, J. W., R. M. Gutierrez-Cernosek, S. F. Cernosek, Jr., and J. N. Pasley. 1980. Effects of adrenocorticotropin on pregnancy and prolactin in mice. Endocrinology. 107:616-621.

43. Christian, J. J. 1964. Actions of ACTH in intact and corticoidmaintained adrenalectomized female mice with emphasis on the reproductive tract. Endocrinology. 75:653-669.

44. Ogle, T. F. 1977. Modification of serum inteinizing hormone and prolactin concentrations by corticotropin and adrenalectomy in adrenalectomized rats. Endocrinology. 101:494-499.

45. Collu, R., Y. Tache, and J. R. Ducharme. 1979. Hormonal modifications induced by chronic stress in rats. J. Steroid Biochem. 11:989-1000.

46. Harms, P. G., P. Langlier, and S. M. McCann. 1975. Modification of stress-induced prolactin release by dexamethasone or adrenalectomy. Endocrinology. 96:475-478. 